\title{
DOES MANAGED CARE CHANGE THE MANAGEMENT OF NONPROFIT HOSPITALS? EVIDENCE FROM THE EXECUTIVE LABOR MARKET
}

\author{
MARIANNE BERTRAND, KEVIN F. HALLOCK, and RICHARD ARNOULD*
}

\begin{abstract}
This paper examines how the managerial labor market in nonprofit hospitals has adjusted to the financial pressures induced by HMO penetration. Using a panel of about 1,500 nonprofit hospitals over the period 1992-96, the authors find that top executive turnover increased following an increase in HMO penetration. Moreover, the increase in turnover was concentrated among the hospitals that had lower levels of economic profitability. While the link between top executive pay and for-profit performance measures was on average very weak, HMO penetration tightened that link: as HMO penetration increased, top executives were compensated more for improving the profitability of their hospitals. These results, while of limited economic magnitude, are qualitatively consistent with the view that HMO penetration has increased the weight assigned to for-profit performance in the management of not-for-profit hospitals.
\end{abstract}

$\mathbf{S}$ ubstantial changes have occurred over the past ten to twenty years in the hospital sector. One of the most important of these changes has without doubt been the growth in Health Maintenance Organiza-

\footnotetext{
* Marianne Bertrand is Professor of Economics, Graduate School of Business, University of Chicago, and Research Associate, NBER. Kevin F. Hallock is Associate Professor, Department of Economics and Institute of Labor and Industrial Relations, University of Illinois at Urbana-Champaign, and Research Associate, NBER. Richard Arnould is Professor, Emeritus, Department of Economics, University of Illinois at Urbana-Champaign. The authors are very grateful to seminar participants at the University of California at Berkeley, the University of Illinois, Princeton University, Texas A\&M University, the AEA Meetings, and the NBER Conference on the Industrial Organization of Healthcare, as well as to Orley Ashenfelter, David Card, Janet Currie, Larry DeBrock, Mark Killingsworth, David Lee, Jonathan Leonard, Darren Lubotsky, Sendhil Mullanaithan, Ronald Oaxaca,
}

tions (HMOs) and Preferred Provider Organizations (PPOs). While in the past hospitals competed mostly on the quality of care they provided, cost-conscious managed care organizations have created growing

Michael Ransom, Clayton Reck, Kathryn Shaw, and Finis Welch for many helpful comments. They also thank Sara Christopher and Srikanth Kadyala for excellent research assistance. This research was supported by the Institute of Labor and Industrial Relations and the College of Business at the University of Illinois, and by a grant from the National Bureau of Economic Research.

Copies of the computer programs used to generate results presented in this paper are available from Marianne Bertrand (marianne.bertrand@gsb. uchicago.edu) or from Kevin Hallock (hallock@ uiuc.edu). Some of the data in the paper were purchased from the American Hospital Association and can be purchased from that association by other researchers. 
financial pressures in this industry. ${ }^{1}$ In this paper, we ask whether the negative income effect associated with the expansion of medical plans has altered the management of nonprofit hospitals. Did nonprofit boards become more profit-oriented in the face of the growing managed care market? This is an especially important question as it touches on the efficiency and viability of maintaining policy incentives to organize along the nonprofit form in an industrial sector that becomes more and more competitive.

Such a change in focus could be expected under at least two theoretical models of nonprofit organizations. Consider first a purely altruistic model wherein nonprofit hospital boards are motivated by a desire to improve social well-being rather than to maximize profits (Drucker 1992). For example, altruistic boards truly value achieving high levels of service quality or providing charitable care. Another natural goal for these boards may be to provide for the needs of many future generations of patients. Negative income pressures (such as those induced by the spread of managed care) endanger intergenerational equity as they seriously heighten the risk of a financial failure. In response, nonprofit boards may decide to make economic survival a primary objective, at least as long as the likelihood of distress stays large.

In the alternative model, nonprofit boards are not fundamentally altruistic but act as if they were. They do so because their incentive to maximize profits is softened by their inability to distribute such profits to themselves (Hansmann 1996). They can only benefit from cost-cutting, quality-reducing activities by increasing their perquisites, not by increasing their cash transfers.

\footnotetext{
${ }^{1}$ Duke (1996) best summarizes these financial pressures as a shift in market power away from hospitals and toward health plans and insurers. In practice, this shift in market power was mainly achieved by expanding the level of competition between hospitals in the same geographic region, as well as lowering hospital utilization rates, leading to overcapacity.
}

Nonprofit boards can therefore commit to higher-quality services than for-profit boards as long as receiving compensation in the form of perquisites is worse than receiving cash (Glaeser and Shleifer 2001). Because a negative shock to income will increase the marginal value of such perquisites, it will also strengthen the for-profit incentives. Hence, both models predict that the nonprofit hospitals that are subject to negative income pressures may start focusing more on economic profits.

Directly assessing whether not-for-profit hospitals have indeed become more driven by, say, accounting rates of return is not an easy task. For example, no simple inference could be made from directly examining trends in hospital outcome measures. Frank and Salkever (2000) documented that profitability margins for not-for-profit hospitals fell substantially in the latter half of the 1980s and remained low thereafter. While this could be construed as evidence that not-for-profit hospitals have not put more weight on economic profitability, it could also mechanically result from the greater financial pressures introduced by the managed care industry. ${ }^{2}$

Our approach in this paper is to indirectly assess any changes in the management of nonprofit hospitals by studying changes in the executive labor market at these hospitals. ${ }^{3}$ We believe that two different aspects of the executive labor market are relevant. First, we ask whether the allocation of managerial talent at the head of nonprofit hospitals was affected by the spread of managed care. We study whether there was an in-

\footnotetext{
${ }^{2}$ Several authors have recently noted a weakening in the provision of charity care as market pressures increase. Currie and Fahr (2004) provided some evidence that managed care reduced the Medicaid caseload in nonprofit hospitals. Similarly, Duggan (2002) showed that nonprofit hospitals that are surrounded by more for-profit hospitals devote a smaller share of their care to the indigent. None of these papers, however, has directly documented a rise in for-profit objectives.

${ }^{3}$ See Newhouse (1970) for an early discussion of nonprofit hospitals.
} 
crease in top executive turnover ${ }^{4}$ with the increase in HMO penetration and, if so, which managers were more likely to be replaced. Evidence that income pressures led to more displacement among poor economic performers would be suggestive of a shift toward a higher valuation of for-profit performance by nonprofit boards.

Second, we exploit some implications of standard agency theory to learn more about the metrics used to evaluate managers by nonprofit boards. In a simple principalagent model, boards of directors tie managerial pay to the organizational outcomes that they value and that are influenced by managerial effort. The work of Murphy (1985), Jensen and Murphy (1990), and scores of others has empirically applied this idea to the for-profit sector. These authors have shown that CEO compensation in publicly traded corporations is linked to measures of economic performance such as accounting rates of return or shareholder wealth. Under the assumption that nonprofit boards also need to provide incentives to their officers, we study which hospital outcomes are correlated with managerial pay. We then ask whether HMO penetration has qualitatively or quantitatively altered the link between managerial pay and these various hospital outcome measures.

While this paper focuses on a very specific sector within the nonprofit world, the question of how financial pressures affect the behavior of not-for-profit organizations is of much wider relevance. It has been anecdotally noted (Weisbrod 1998) that many nonprofit sectors have become more and more commercialized. Higher education, museums, and public television broadcasting are often cited as examples. Going beyond the anecdotal evidence and under-

\footnotetext{
${ }^{4} \mathrm{We}$ are unable to distinguish between forced and unforced turnovers. We share this limitation with many other papers studying managerial turnover in the for-profit sector. The few papers that have been able to make that distinction used press release information. Unfortunately, similar information is not widely available for this sector of the economy.
}

standing the role that financial pressures have played in this apparent change in behavior is important in assessing the future of the nonprofit form.

Our focus on the hospital industry is in large part motivated by the intrinsic importance of this industry as the largest nonprofit sector in the economy. ${ }^{5}$ It is also motivated by two more practical issues. First, measures of not-for-profit performance can more easily be computed in this sector than in most other nonprofit sectors. For example, number of nurses or doctors per patient day or dollars spent on program services per patient day capture, admittedly imperfectly, some aspects of the quality of care. ${ }^{6}$ It is more difficult to think of reasonable nonprofit objective proxies for many of the other nonprofit sectors. Moreover, even if one can find such good proxies, data limitation issues are often binding. Second, the growing involvement of managed care in the hospital industry offers a unique setting in which to study the effect of a negative income shock on nonprofits' behavior.

Our findings complement previous work on hospital conversions. Several authors (Cutler and Horwitz 2000; Weisbrod 1998; Goddeeris and Weisbrod 1998; Abelson 1998) have documented a rather rapid shift to for-profit status in the hospital market. Cutler and Horwitz (2000) noted that these conversions are driven, at least in part, by

\footnotetext{
${ }^{5} \mathrm{~A}$ common measure of nonprofit size is annual expenses. If operating public charities are categorized into nine groups, their percentage of total expenses are the following: Arts, Culture, and $\mathrm{Hu}$ manities, 2.4\%; Education, 17.4\%; Environment/ Animals, $0.8 \%$; Health, $62.7 \%$; Human Services, $11.5 \%$; International Affairs, $0.8 \%$; Public Societal Benefit, 2.9\%; Religion-Related, 0.7\%; and Unknown, $0.7 \%$. Furthermore, hospitals and primary facilities make up roughly half of the entire health category. (Stevenson, Pollak, Lampkin, Pettit, and Stengel 1997:31-32.)

${ }^{6}$ Optimally, we would have liked to use better proxies of quality of care, such as risk-adjusted mortality rates. Unfortunately, such mortality rates exist for only a subsample of the hospitals in our sample and, most important, are not available to us in a panel format.
} 
the heightened financial pressures in the new health care market. Our study casts light on whether market pressures have led to a change in organizational management even among the hospitals that maintain their nonprofit status. To the extent that they have, it is also possible that such changes in management could create enough tension inside the nonprofit organizations to ultimately lead to conversions.

Our findings can also be compared with anecdotal and survey evidence, such as in Frank and Salkever (2000). These authors reported results of focus group discussions with (mostly nonprofit) hospital managers in the Boston and Chicago areas. Frank and Salkever (2000) summarized the contents of these discussions as "implying a large weight on current and future profits in the face of perceived financial and competitive pressures."

\section{Data Description and Empirical Approach}

We use three different data sources in this paper. The first data source, which includes detailed compensation information on managers of nonprofit hospitals as well as some accounting and financial variables for the hospitals, is the Internal Revenue Service (IRS). The second data source is the American Hospital Association (AHA) Annual Survey. ${ }^{7}$ This survey includes information on a large set of hospital characteristics as well as the names of hospital top managers, which we use to compute managerial turnover. The last data source, created by Lawrence Baker using data from the Group Health Association of America's National Directory of HMOs, contains information on HMO penetration rates.

\section{IRS Data}

The IRS data come from the tax returns of "501c (3)" tax-exempt organizations and

\footnotetext{
${ }^{7}$ Merging AHA and IRS data was difficult and had to be done by hand, since organization identifiers did not match across samples (nor did precise names of organizations, in many cases).
}

cover the period 1992 to 1996 . The base sample includes more than 25,000 organizations filing Form 990 returns. We selected the sub-grouping for hospitals and related primary medical care facilities based on the National Taxonomy of Exempt Entities (NTEE) industry codes of nonprofits.

For each top executive we collected three measures of compensation and a host of accounting and financial information on the hospital he or she manages. To compute the compensation measure, we extracted information on (1) base compensation, including "salary, fees, bonuses, and severance payments paid" (Internal Revenue Service 1996); (2) contributions to employee benefit plans and deferred compensation, including "medical dental and life insurance" (Internal Revenue Service 1996); and (3) expense account and other allowances, including "expense allowances or reimbursements that the recipient must report as income on their separate income tax returns." ${ }^{8}$ Examples include amounts for which the recipient did not account to the organization or allowances that "were more than the payee spent on serving the organization." Organizations are required to include such payments as "the value of the personal use of housing, automobiles, or other assets owned or leased by the organization" (Internal Revenue Service 1996). For the purpose of our paper, we combine these three variables into a single measure of "total compensation." As shown in Table 1 , the average top officer of the hospitals in our sample earned $\$ 241,000$ (1996 dollars). Note that one major weakness of the IRS data compared to standard databases on for-profit managers' compensation is the absence of demographic controls. We observe neither the age nor the tenure of the top executives in our sample.

Table 1 also reports means and standard errors for a set of the accounting and financial variables that we directly extracted or

\footnotetext{
${ }^{8}$ Because the IRS data do not report salary and bonus separately, we are not able to study the differential impact of HMO penetration on these various components of compensation.
} 
Table 1. Summary Statistics for HMO Penetration, Managers, and Hospitals.

\begin{tabular}{|c|c|}
\hline Characteristic & All Hospitals \\
\hline \multicolumn{2}{|l|}{ Market Pressure } \\
\hline HMO Penetration Rate & $\begin{array}{c}0.154 \\
(0.002)\end{array}$ \\
\hline \multicolumn{2}{|l|}{ Hospital Managers (thousands) } \\
\hline Pay of Top Manager (levels) & $\begin{array}{c}240.958 \\
(8.451)\end{array}$ \\
\hline Pay of Top Manager (logs) & $\begin{array}{c}5.181 \\
(0.013)\end{array}$ \\
\hline Managerial Turnover (fraction) & $\begin{array}{c}0.129 \\
(0.005)\end{array}$ \\
\hline \multicolumn{2}{|l|}{ Hospital Financials (thousands) } \\
\hline Assets & $\begin{array}{c}123,016 \\
(3,314)\end{array}$ \\
\hline Revenue & $\begin{array}{c}119,158 \\
(2,700)\end{array}$ \\
\hline Expenses & $\begin{array}{c}113,375 \\
(2,485)\end{array}$ \\
\hline Return $=($ Rev. - Exp. $) /$ Total Assets & $\begin{array}{c}0.047 \\
(0.001)\end{array}$ \\
\hline Profit Margin = (Rev. - Exp. $) /$ Rev. & $\begin{array}{c}0.048 \\
(0.001)\end{array}$ \\
\hline Program Service (PS) Profit Margin & $\begin{array}{c}0.145 \\
(0.002)\end{array}$ \\
\hline Leverage $=$ Liabilities $/$ Total Assets & $\begin{array}{c}0.482 \\
(0.003)\end{array}$ \\
\hline \multicolumn{2}{|l|}{ Nonprofit "Performance" } \\
\hline Ln(Program Exp./Patient Days) & $\begin{array}{c}-0.163 \\
(0.010)\end{array}$ \\
\hline Ln(Nurses/Patient Days) & $\begin{array}{c}-5.875 \\
(0.007)\end{array}$ \\
\hline Ln(Doctors/Patient Days) & $\begin{array}{l}-9.157 \\
(0.023)\end{array}$ \\
\hline $\mathbf{N}$ & 4,237 \\
\hline
\end{tabular}

Notes: All data are reported in thousands of dollars (real 1996 dollars) adjusted using the Consumer Price Index. Standard errors are in parentheses. Precise definitions of variables and data description are in the text.

Sources: IRS tax form 990 and the AHA Annual Survey for individual organizations for 1992-96.

constructed from the IRS. For example, the average assets, revenue, and expenses for the nonprofit hospitals in our sample over this period are $\$ 123$ million, $\$ 119$ million, and $\$ 113$ million, respectively. We will use the measures of return on assets and profit margins summarized in Table 1 as proxies for for-profit objectives.

\section{AHA Annual Survey Data on Hospitals}

In order to complement the IRS data, we collected additional information on hospitals and hospital managers from the American Hospital Association (AHA) for the years 1992-96. Each year, the AHA completes an "annual survey of hospitals" and then distributes (for a fee) the "Annual Survey of Hospitals Data Base." These data contain a wide variety of variables, including hospital location, hospital ownership form, types of facilities and services provided, number of beds, inpatient days, and size of staff. We restrict our sample to general medical and surgical hospitals (service code 10 in the AHA data).

Among some specific data fields that we use from the AHA are the Zip Code of the hospital (so we can merge to the HMO penetration rates below) and the name of the hospital (so we can merge to the IRS data). We also concentrate on a variable that contains the name of the top administrator of the hospital. We use this variable to construct our measure of top executive turnover. Since the names of the hospital managers are included as text, creating a variable for managerial turnover required us to check for name changes by hand. Table 1 shows that the average turnover rate for managers of hospitals in our sample is 0.129 . We also collected information on the number of Medicaid patients, the number of full-time doctors, and the number of full-time registered nurses that we normalized by the number of inpatient days. As usual, the inpatient days measure is adjusted to account for the number of "oneday" admissions. Later in the analysis, we will use these measures as proxies for the provision of charitable care and for the quality of hospital care.

\section{HMO Penetration Rates}

Our measure of managed care penetration is the county/year-level HMO market 
share. This market share is defined as the ratio of the number of HMO enrollees to the number of beneficiaries in the county. The data were assembled and provided to us by Lawrence Baker. The basic source for the data is the National Directory of HMOs, which is published each year by the Group Health Association of America. The directory surveys all HMOs in the United States and questions them about the area they service and their total enrollment. Using these data is difficult because HMOs can span several different regions and because "HMO enrollment may be concentrated near HMO headquarters or...HMOs may locate their headquarters in areas where their enrollment is concentrated" (Baker and Brown 1999). However, Baker and Brown found that their HMO measures were relatively insensitive to alternative ways of dealing with these issues. Market share estimates were then created as the fraction of the total population enrolled in $\mathrm{HMO}$ plans (Baker and Brown 1999). Baker (1995) provides many more details on the construction of the data. The average level of HMO penetration in our sample is $15.4 \%$ (Table 1).

\section{HMO Penetration and Managerial Talent}

Under the hypothesis that HMO penetration pressures forced the boards of nonprofit hospitals to put more weight on economic profitability, one might expect such pressures to be accompanied by changes in the pool of managerial talent at those hospitals. If economic profitability became an increasingly important goal, the attractiveness of managers who are less prepared or trained to achieve such goals may have decreased. In addition, not-for-profit hospitals may now have to tap more in to the pool of for-profit managers to find individuals with the appropriate sets of skills. This might create upward pressures on managerial pay in the not-for-profit sector, as for-profit organizations typically reward their managers with much higher compensation. In this section, we investigate whether such changes in the market of not- for-profit hospital managers indeed occurred.

We start by studying in detail the relationship between managerial turnover and the rate of $\mathrm{HMO}$ penetration. ${ }^{9}$ The dependent variable in all regressions in Table 2 is a dummy variable that equals 1 if the manager is newly appointed, 0 otherwise. All regressions are estimated using a linear probability model and include year fixed effects to account for any aggregate shocks to turnover rates. In column (1), we simply regress this turnover dummy on HMO penetration. Reported standard errors are corrected for clustering of the error term at the Zip Code level.

The estimated coefficient on HMO penetration is positive and statistically significant, indicating a higher turnover rate when HMO penetration is higher. We find that a 1 percentage point increase in HMO penetration is associated with a 0.105 percentage point increase in the probability of top executive turnover. To give a better sense of economic magnitude, we computed the average turnover rate in areas that are above and below average levels of HMO penetration. In areas below average, the average turnover rate was $11.6 \%$; in areas above average, the average turnover rate was $14.7 \%$.

Any causal interpretation of this effect is hindered by the possibility of omitted variable biases. For example, Baker and Corts (1996) noted that HMOs are more likely to spread first in areas that are dominated by large firms and white-collar workers. Because their residents are likely of aboveaverage affluence, such areas might also attract more modern, better-equipped hospitals, as well as higher-profile administra-

\footnotetext{
${ }^{9}$ As discussed above, we are not able to separate turnover events into firings, quits, and retirements. Also, we do not have information on managers' age, which would constitute a natural proxy for retirements. However, we see no obvious reason why there would be a systematic positive correlation between managers' age and HMO penetration, and therefore do not believe that our findings in this section are driven by retirements.
} 


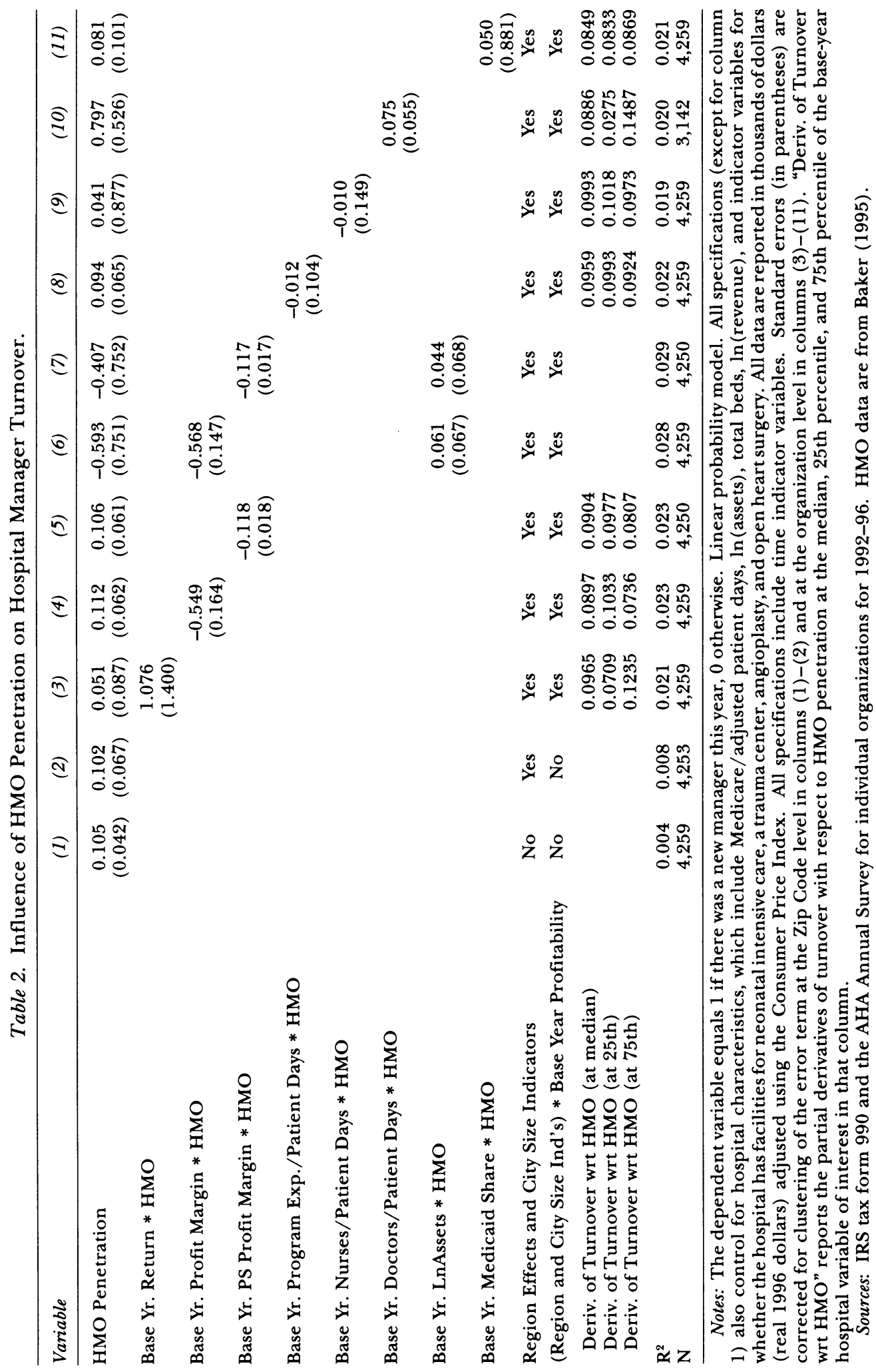


tors. If differential turnover patterns (and compensation levels) are found for managers across such different geographic areas, ascribing that variation to HMO penetration might very well be a misconstruction. In column (2), we partially address this concern by adding a vector of controls for hospital and area characteristics. More specifically, we add 9 region dummies and 7 city size dummies that should capture some of the variation in income across areas. ${ }^{10}$ We also add a vector of hospital characteristics, including Medicare per adjusted patient day, $\ln$ (assets), total beds, $\ln$ (revenue), and indicators for whether the hospital has facilities for prenatal care, a trauma center, angioplasty, and open heart surgery. Column (2) shows that the inclusion of these additional controls does not affect the economic significance of the coefficient on HMO penetration (but the $\mathrm{p}$-value now rises to 0.10 ).

A higher level of turnover in markets with higher $\mathrm{HMO}$ penetration rates is only a necessary condition to support the hypothesis of a re-allocation of managerial talent described above. More important, we would like to establish whether the increased managerial turnover was concentrated among the hospitals with the worst for-profit performance results. ${ }^{11}$ In other words, are managers with lower levels of profitability more likely to be replaced when financial pressures get more intense? The

\footnotetext{
${ }^{10}$ The seven city size dummies: non-metropolitan area; metropolitan area with less than 100,000 people; between 100,000 and 250,000; between 250,000 and 500,000 ; between 500,000 and $1,000,000$; between $1,000,000$ and 2,500,000; and over 2,500,000.

${ }^{11}$ One would also want to know more about the characteristics of the newly hired managers. For example, one would like to know whether the newly hired executives have received more business training. Unfortunately, this information is not available in our data. Included in Cutler and Seinfeld (2000), however, is a careful analysis of the backgrounds of hospital managers. Cutler and Seinfeld used data from the 1982 and 1991 American College of Health Care Executives. One of their findings that is especially relevant for our work was that "financial acumen matters" (p. 4).
}

remainder of Table 2 addresses this question.

Columns (3)-(7) display the results of estimations investigating whether the increase in turnover was higher among hospitals that had lower base-year levels of return on assets or lower base-year profitability margins. Return on assets is defined as (total revenue - total expense)/(total assets). We construct two different profitability margins. First, we define total profitability margin as (total revenue - total expense)/(total revenue). We also construct a profitability margin on program services, which is defined as (program service revenue - program service expense)/ (program service revenue).$^{12}$ The base year is defined for each hospital as the first year a hospital appears in our dataset. Because of the concerns raised above regarding the non-randomness of HMO penetration, regressions (3) $-(7)$ also allow for interaction terms between the region and city size dummies and these base-year measures of economic profitability. Also, all of these regressions include the vector of controls for hospital characteristics described above. The coefficient of interest in all these regressions is that on the interaction terms between HMO penetration and the baseyear profitability measures. Finally, standard errors here are clustered at the hospital level.

Column (3) shows no significant pattern of $\mathrm{HMO}$-induced turnover in hospitals with lower rates of return on assets. However, columns (4) and (5), respectively, show that HMO-induced turnover was higher in hospitals with lower base-year total profitability margins and lower base-year profitability margins on their program services operations. To give a better sense of economic magnitude, we performed a simple cross-tabulation of average turnover rates by HMO penetration (below and above

\footnotetext{
${ }^{12}$ This is relevant since program services are the part of revenue that is actually concentrated on directly serving others, rather than (for example) fundraising or administration.
} 
average) and base-year profitability margin (below and above average). In low HMO penetration areas, the average turnover rate is about $13.3 \%$ in low-performance hospitals and $11.7 \%$ in high-performance ones. In high HMO penetration areas, the average turnover rate is about $17 \%$ in low-performance hospitals and $12.9 \%$ in high-performance ones. We also report at the bottom of Table 2 partial derivatives of turnover with respect to HMO penetration computed at the median, at the 25 th percentile, and at the 75 th percentile of the distributions of these base-year profitability measures. As one can see in column (4), for example, the sensitivity of turnover to $\mathrm{HMO}$ penetration increases by more than $40 \%$ as one moves from the 25 th to the 75 th percentile of the base-year profitability margin distribution.

Because profitability margins may be correlated with other hospital characteristics, one concern is that the higher HMOinduced turnover rate for low economic performers may be induced by such other hospital characteristics. One such important characteristic is hospital size. Therefore, in columns (6) and (7), we replicate columns (4) and (5) but allow for an additional interaction term between $\mathrm{HMO}$ penetration and base-year hospital size, which we measure as the logarithm of total assets in the first year a given hospital appears in our dataset. Also, we allow for interactions between the region and city size dummies and base-year hospital size. The estimated coefficients on the interaction term between HMO penetration and the profitability margin measures are unaffected.

The last four columns of Table 2 ask whether there was any differential increase in HMO-induced turnover based on hospital base-year measures of not-for-profit performance. To implement this, we use 3 different proxies for quality of care: program services expenditures per adjusted patient day, number of full-time registered nurses per adjusted patient day, and number of full-time physicians and dentists per adjusted patient day (columns 8,9 , and 10, respectively). We also compute a proxy for provision of charity care: the base-year share of Medicaid patients (column 11)..$^{13}$ The regressions in the last 4 columns follow the structure of those in columns (3) to (5), in that we also allow for interactions between the region and city size dummies and the base-year not-for-profit performance measures.

All estimated coefficients on the interaction between HMO penetration and the not-for-profit performance measures are statistically insignificant. The only marginally significant interaction term is that between HMO penetration and number of full-time physicians and dentists per adjusted patient day ( $\mathrm{p}$-value $=0.17)$. That coefficient is positive, indicating that the HMO-induced increase in turnover was higher among hospitals that were more doctor-intensive. The reported partial derivatives of turnover with respect to HMO penetration computed at the median, the 25 th percentile, and the 75 th percentile of the distributions of these base-year measures of quality of care indicate that all of these estimated interaction effects are economically small, except again for the number of full-time physicians and dentists per adjusted patient day.

Overall, the evidence in Table 2 is consistent with the possibility that HMO penetration leads to the replacement of the top managers who are the least able to fulfill for-profit goals. Also, while we do not want to push this result too far, it is interesting that the top executives who have achieved a good quality of care (that is, the top managers in hospitals with a high base-year level of program service expenditure or full-time staff per adjusted patient day) do not appear more likely to be replaced. This might indicate that while for-profit objectives appear to have become more important for not-for-profit boards, quality objectives did not become a "bad."

What do all of these changes imply for top executives' pay? Intuitively, one may

\footnotetext{
${ }^{13}$ We would also like to use the fraction of uninsured patients as another proxy for the provision of charity care, but that information in not available in the AHA data.
} 
expect the spread of managed care to lead to an increase in nonprofit hospital managers' pay. ${ }^{14}$ First, nonprofit hospital boards may now have to tap into the pool of forprofit hospitals' managers when looking to replace previous managers with low business management skills. And for-profit hospitals typically pay higher salaries. ${ }^{15}$ Moreover, even among the hospitals that are not replacing their top manager, the higher risk of turnover that is apparently associated with wider HMO presence could in itself generate higher compensating salaries. ${ }^{16}$

Unfortunately, our ability to carefully investigate this question is limited by the absence of good demographic controls for managers in our data. Because we know neither top managers' age nor their experience (either total experience or length of tenure on their current job), we cannot easily account for these important determinants of pay in our analysis. Keeping this caveat in mind, we study the effect of HMO penetration on mean pay in Table 3 .

In column (1), we explore the correlation between HMO penetration and mean pay, only controlling for year fixed effects. Standard errors are corrected for clustering of the error term at the Zip Code level. The effect is economically large and statistically very significant. As we discussed above, however, HMO penetration is not

\footnotetext{
${ }^{14}$ An opposing force-one tending to lower managerial pay-could come from the wave of mergers and consolidations that have hit the hospital industry with managed care expansion. Such restructuring may have introduced more slack in the market for hospital top executives.

${ }^{15}$ Roomkin and Weisbrod (1999), for example, studied the 1992 Hospital Compensation Survey conducted by Hay management consultants and found that the pay of a top executive in for-profit hospitals was higher than the pay of an executive holding a similar job in a nonprofit hospital of similar size.

${ }^{16}$ Below, we discuss another reason for an expected increase in mean pay. Pay seems to have become riskier because, as we will show, the link between pay and economic performance has become tighter. This would require a standard upward adjustment of mean pay in order to keep a risk-averse agent indifferent between the two contractual environments.
}

random across areas, and this positive correlation may in part be capturing the fact that $\mathrm{HMO}$ penetration is higher in richer areas. In column (2), we replicate column (1) but further control for region and city size dummies. We also include the now standard vector of controls for hospital characteristics. The correlation between managerial pay and HMO penetration stays positive and statistically significant, but the size of the effect is now much smaller. As discussed before, this likely reflects a selective entry of HMOs into different geographical markets. For example, the pay of top executives is much lower among the hospitals that have a larger share of Medicaid patients. Hence, part of the large positive coefficient on HMO penetration in column (1) simply comes from the fact that HMOs are less likely to have a strong presence in markets where lower-income people are more numerous.

A more extreme way to account for any unobservable factors that might be correlated with HMO penetration is to look at how changes in managerial pay within hospitals are related to the level of HMO penetration. We do this in column (3), where we replace region and city size dummies with hospital fixed effects. The estimated coefficient on HMO penetration is now statistically insignificant, with a negative point estimate.

What can explain this lack of a positive pay response in column (3)? First, an obvious limitation of any inference based on a hospital-fixed effects approach is the very short panel length in our data. There is only limited residual variation in $\mathrm{HMO}$ penetration once one controls for years and hospital fixed effects. Another possible explanation we already alluded to revolves around the lack of demographic controls for the managers. If newly appointed executives are younger and less experienced, they might on net be paid less than their predecessors. In a regression not reported here, we find that turnover is indeed on average associated with a reduction in mean pay of about $5 \%$.

One way to get around some of these limitations is to ask whether the turnover 
Table 3. The Effect of HMO Penetration on Hospital Manager Pay.

\begin{tabular}{|c|c|c|c|c|c|c|c|}
\hline Variable & (1) & (2) & (3) & (4) & $(5)^{2}$ & (6) & $(7)^{2}$ \\
\hline HMO Penetration & $\begin{array}{c}1.7910 \\
(0.1582)\end{array}$ & $\begin{array}{c}0.482 \\
(0.184)\end{array}$ & $\begin{array}{l}-0.139 \\
(0.534)\end{array}$ & $\begin{array}{c}0.435 \\
(0.191)\end{array}$ & $\begin{array}{c}0.428 \\
(0.190)\end{array}$ & $\begin{array}{l}-0.154 \\
(0.537)\end{array}$ & $\begin{array}{r}-0.236 \\
(0.550\end{array}$ \\
\hline Managerial Turnover & & & & $\begin{array}{l}-0.121 \\
(0.062)\end{array}$ & $\begin{array}{l}-0.178 \\
(0.135)\end{array}$ & $\begin{array}{l}-0.080 \\
(0.074)\end{array}$ & $\begin{array}{r}-0.139 \\
(0.161)\end{array}$ \\
\hline $\begin{array}{l}\text { Managerial Turnover * } \\
\text { HMO Penetration }\end{array}$ & & & & $\begin{array}{c}0.351 \\
(0.267)\end{array}$ & $\begin{array}{c}0.434 \\
(0.379)\end{array}$ & $\begin{array}{l}0.183 \\
(0.291)\end{array}$ & $\begin{array}{r}0.248 \\
(0.391)\end{array}$ \\
\hline Hospital Characteristics ${ }^{b}$ & No & Yes & Yes & Yes & Yes & Yes & Yes \\
\hline $\begin{array}{l}\text { Region Effects and City } \\
\text { Size Indicators }\end{array}$ & No & Yes & No & Yes & Yes & No & No \\
\hline Hospital Fixed Effects & No & No & Yes & No & No & Yes & Yes \\
\hline $\begin{array}{l}\mathrm{R}^{2} \\
\mathrm{~N}\end{array}$ & $\begin{array}{l}0.0640 \\
4,300\end{array}$ & $\begin{array}{l}0.339 \\
4,294\end{array}$ & $\begin{array}{l}0.799 \\
4,294\end{array}$ & $\begin{array}{l}0.339 \\
4,259\end{array}$ & $\begin{array}{l}0.346 \\
4,259\end{array}$ & $\begin{array}{l}0.800 \\
4,259\end{array}$ & $\begin{array}{l}0.800 \\
4,259\end{array}$ \\
\hline
\end{tabular}

Notes: The dependent variable is $\ln$ (total compensation). OLS regressions. All data are reported in thousands of dollars (real 1996 dollars) adjusted using the Consumer Price Index. All specifications include time indicator variables. Standard errors (in parentheses) are corrected for clustering of the error term at the Zip Code level in columns (1)-(3) and at the organization level in columns (4)-(7).

${ }^{2}$ Also controls for interactions between turnover and region and city size dummies.

bHospital characteristics include Medicare/adjusted patient days, ln(assets), total beds, $\ln$ (revenue), and indicator variables for whether the hospital has facilities for neonatal intensive care, trauma center, angioplasty, and open heart surgery.

Sources: IRS tax form 990 and the AHA Annual Survey for individual organizations for 1992-96. HMO data are from Baker (1995).

that happens in times of heightened HMO presence results in relatively smaller pay cuts. This would indicate that the CEOs newly appointed in markets where HMO penetration is higher are systematically different, perhaps because of their superior business management skills. We explore this approach in columns (4) and (5). In practice, we now interact HMO penetration with a turnover dummy, and ask whether the changes in compensation that occur at turnover are systematically different when HMO penetration is high. The regression in column (4) includes year fixed effects, region and city size fixed effects, and the vector of hospital characteristics. In column (5), we also allow for interactions between the turnover variable and the region and city size dummies. The interaction term between turnover and HMO penetration is in both cases, as expected, positive, but noisily estimated. Columns (6) and (7) replicate columns (4) and (5) but replace the region and city size dummies with hospital fixed effects. Again, the estimated coefficients on the interaction term between HMO penetration and turnover are positive, but not statistically significant.

Another explanation for the lack of a strong positive pay effect could be that part of the effect of the HMO penetration was to reduce managerial rents in the not-forprofit sector. Such a view is at first glance inconsistent with the evidence in Roomkin and Weisbrod (1999), indicating larger pay levels in the profit sector than in the notfor-profit sector within specific managerial occupation and hospital size cells. However, their measure of pay may not capture a set of perks that is easier to detect in a notfor-profit environment. Moreover, various legislative efforts to cap the salaries of hospital executives and other hospital employees could be viewed as symptomatic of excess pay in that sector (see, for example, Nemes 1992). In support of that alternative explanation, we found (in results not reported here but available from the authors upon request) that the increase in 
turnover following HMO penetration was highest among the hospitals that paid the largest wage premium to their top executives.

\section{Has HMO Penetration Changed the Pay-for-Performance Relationship?}

The turnover findings in the previous section provide suggestive evidence that managed care pressures have caused the removal of less financially oriented managers. More generally, however, HMO penetration may have driven nonprofit boards to reconsider the objective function they want to maximize and what goals they want their executives, whether newly appointed or not, to fulfill. As we discussed in the introduction, the approach we follow to address this question is to ask whether the nature of the pay-for-performance relationship for not-for-profit hospital managers is affected by HMO penetration.

This section has two parts. First, we describe the basic pay-for-performance relationship in these data, ignoring the HMO penetration dimension. Then we ask whether the relationship between pay and the various performance indicators has been affected by HMO penetration.

\section{The Basic Pay-for- \\ Performance Relationship among Not-for-Profit Managers}

Although many papers have been written on the pay and performance of CEOs of for-profit firms, there is very little equivalent empirical work for the nonprofit sector. Hallock (2002) studied a panel of over 30,000 nonprofit organization-years constructed from IRS data. He found that the size of the organization, as measured by assets, was strongly linked to managerial pay, even after controlling for individual organization fixed effects. ${ }^{17}$ In fact, no

\footnotetext{
${ }^{17}$ Oster (1998) found a similar result using data from five separate industries. Hallock (2004) specifically compared managerial compensation in for-profit and nonprofit organizations.
}

other performance measure, either forprofit or not-for-profit, appears to have had a statistically significant effect on pay. ${ }^{18}$ Roomkin and Weisbrod (1999) analyzed data from 6,500 general and specialty hospitals in the United States using data from a 1992 survey of Hay Management consultants. Among their findings was that pay was higher in the for-profit sector and that the composition of pay (base pay versus bonus) differed by organizational form. They found that bonuses were larger in size in the forprofit sector. They therefore concluded that for-profit hospitals provide more incentives to managers than do nonprofit hospitals. ${ }^{19}$

Table 4 examines the basic pay-for-performance relationships in our data. Panel A focuses on economic performance measures. Panel B considers non-economic ("nonprofit") performance measures. All regressions are estimated using Ordinary Least Squares. The dependent variable in all regressions is the logarithm of total compensation (as defined above). All regressions include year fixed effects. Standard errors are corrected for clustering of the error term at the hospital level.

We start with the pay-for-economic-performance relationship (Panel A). We consider the three measures of economic performance described above: return on assets, overall profit margin, and profit margin from program services. Following previous literature, we also consider net assets, the sum of the organization endowment, and retained earnings, as alternative performance measures.

\footnotetext{
${ }^{18}$ This, Hallock (2002) conceded, could be due to the wide variety of sectors spanned by his data set. It might be difficult to define a not-for-profit performance measure that is relevant across such a large and diverse array of organizations.

${ }^{19}$ Ballou and Weisbrod (2003), following up on Roomkin and Weisbrod (1999), showed that there may be differences in incentive contracts across different hospital types. Pink and Leatt (1991) studied hospitals in Ontario using cross-sectional data. Preyra and Pink (2001) found that hospital CEOs in publicly traded firms earn "twice as much, on average, as those in similarly sized nonprofit hospitals."
} 


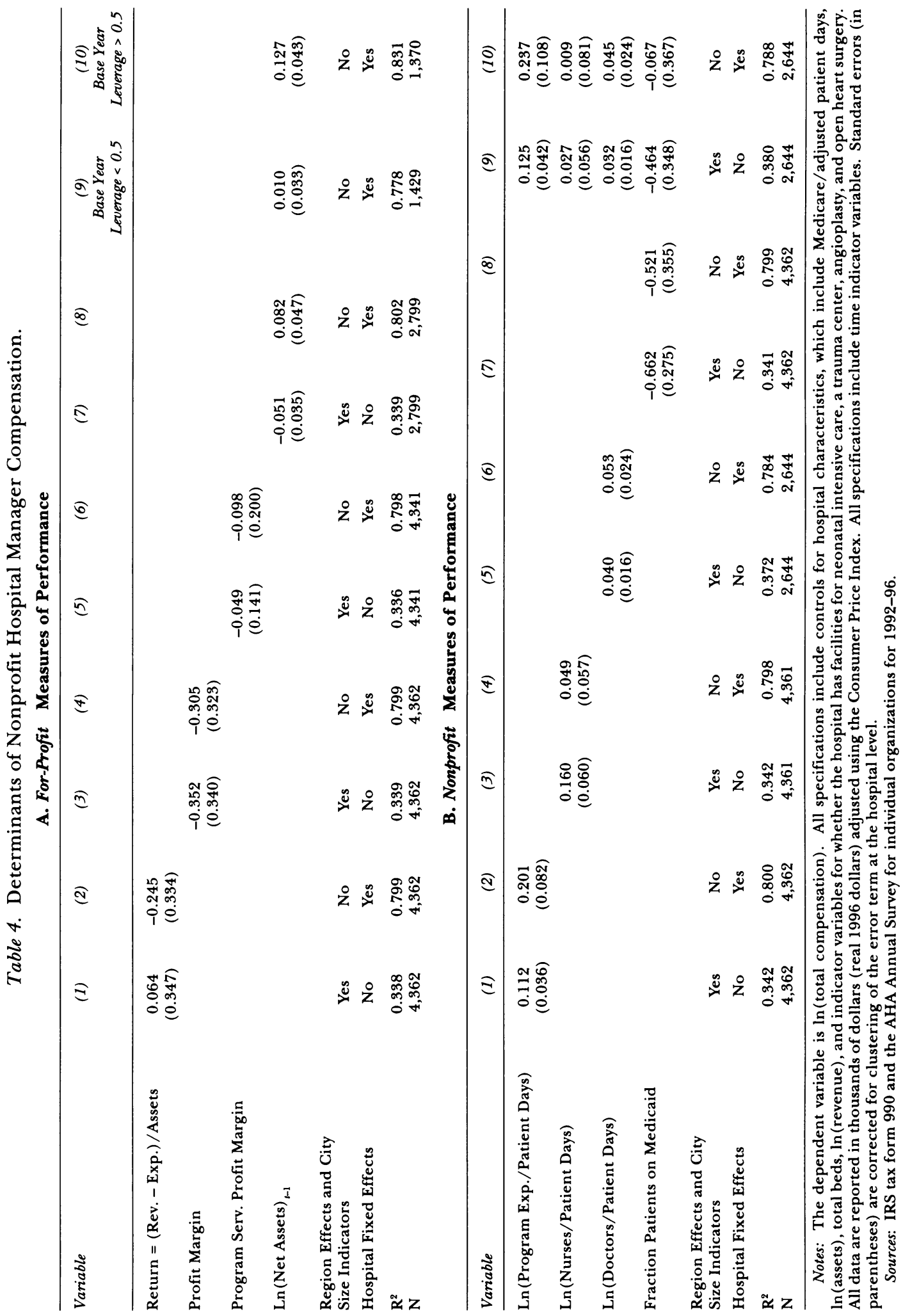


Column (1) regresses managerial compensation on return on assets, controlling for region and city size dummies as well as the vector of hospital characteristics. The point estimate on return on assets is positive but statistically insignificant. Column (2) replicates column (1) but replaces the region and city size dummies with hospital fixed effects. Again, we find no statistically significant relationship between pay and return on assets, and the point estimate on the return on assets coefficient is now negative. Columns (3) and (4) replicate columns (1) and (2) but use total profit margin as an alternative economic performance measure. In both regressions, the point estimate on the performance variable is negative but statistically insignificant. The same patterns hold in columns (5) and (6), where the performance measure is profit margin on program services.

In columns (7) to $(10)$, we use the logarithm of net assets as the performance measure. Again, net assets represent the sum of retained earnings and the organization endowment. It represents the part of total assets that is not financed though liabilities. We experimented with using current and lagged measures of $\ln$ (net assets), and we show results using the lagged performance variable, as they appeared to fit the data better. While there is no statistically significant relationship between pay and net assets when we look within region and city size categories (column 7), we do find a positive relationship between managerial pay and net assets when we account for hospital fixed effects (column 8). We find that top executives are rewarded with higher compensation when they increase the size of their net assets. This suggests that at least some financial objectives matter in setting top executive compensation in non-profit hospitals. The size of this effect is, however, quite small: a $1 \%$ increase in net assets leads to a $0.082 \%$ increase in compensation.

We refine this finding in columns (9) and (10). We split our original sample into two subgroups based on the base-year financial leverage (liabilities to total assets ratio) of the hospitals in our sample. Be- cause the median base-year leverage is about 0.5 , we break the sample into two groups around that cutoff. We then replicate the specification in column (8) on these two subsamples. Quite strikingly, we find that only among the most financially constrained hospitals does the link between pay and net asset growth exist (column 10). One interpretation of this effect is that, more than a reward for achieving high economic performance, the link between pay growth and net asset growth could represent boards' desire to maintain sources of funds for future development and future provision of program services. Such concerns for maintaining internal funds must be especially salient in not-for-profit organizations that have no access to equity finance.

To summarize Panel A, the idea that pay and economic performance are tightly linked in not-for-profit hospitals does not receive strong support in our data. In fact, when we focus on the hospitals that have not exhausted their debt capacity (column 9 ), we find no evidence of a pay for economic performance link.

Panel B provides a similar analysis for not-for-profit measures of performance. As described above, we have created several measures of not-for-profit performance from our AHA and IRS data. Our proposed measures of quality of care are $\ln$ (program service expenses/adjusted patient days), $\ln$ (number of full-time registered nurses on payroll/adjusted patient days), and $\ln$ (number of full-time doctors and dentists on payroll/adjusted patient days). We use the share of Medicaid patients as a measure of charity care. The structure of Panel B follows that of Panel A. For each not-for-profit performance measure, we present first the results with region and city size controls (odd columns) and then the results with hospital fixed effects (even columns). All regressions include year fixed effects and the vector of hospital characteristics. Standard errors are clustered at the hospital level.

We find that more program services expenditures per patient day (columns 1 and 2), more nurses per patient day (columns 3 and 4), and more doctors per patient day 


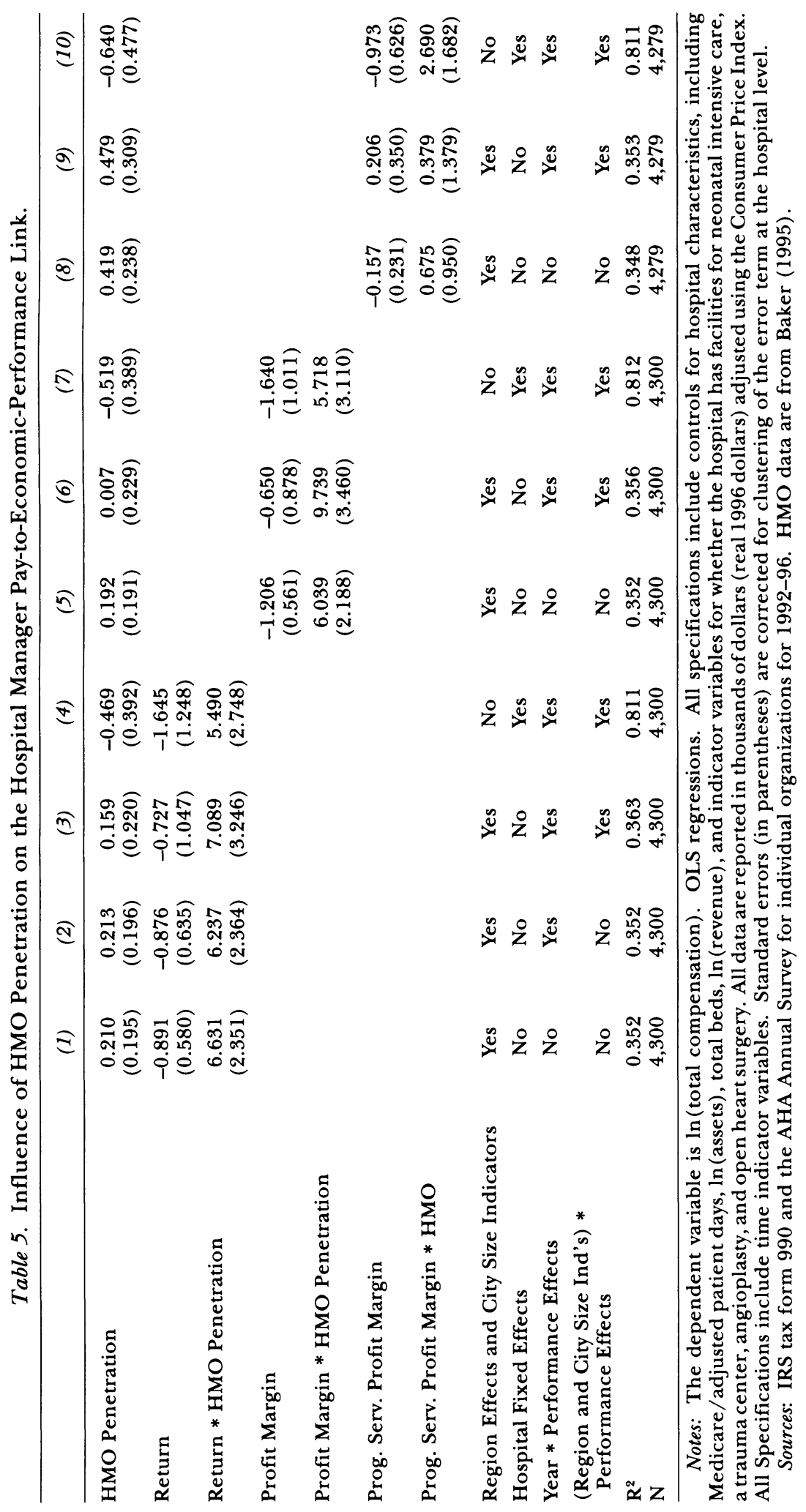


(column 5 and 6) all imply a higher level of managerial pay. ${ }^{20}$ All of these effects are statistically significant, except for number of nurses per patient in column (4) ${ }^{21}$ For example, a $10 \%$ increase in program services expenses per patient increases managerial pay by $2.01 \%$ (column 2 ).

While there appears to be a reward for quality of care, we find, if anything, a negative relationship between pay and fraction of patients on Medicaid (columns 7 and 8), which could indicate that managers are not encouraged by boards to provide charity care to their community. That negative relationship is statistically significant in column (7) but not in column (8).

Columns (9) and (10) consider the joint effect of all these nonprofit performance measures on managerial pay. Only the positive coefficients on $\ln$ (program service expenses/adjusted patient days) and $\ln$ (number of full-time doctors/adjusted patient days) appear statistically robust. The negative impact of the Medicaid market share becomes both economically and statistically less significant. ${ }^{22}$

\section{Effect of HMO Penetration}

In the previous section, we studied the basic relationship between the pay of top not-for-profit hospital executives and vari-

\footnotetext{
${ }^{20}$ In contrast, Brickley and Van Horn (2002) found "no evidence that nonprofit boards provide CEO incentives to care about more than the bottom line."

${ }^{21}$ Note that the coefficient on number of nurses per adjusted patient day becomes statistically significant in a regression that includes state fixed effects and hospital characteristics but excludes hospital fixed effects.

${ }^{22}$ Note that the coefficients on program services expenses per adjusted patient day and number of doctors per adjusted patient day remain unchanged when we directly control for the logarithm of the number of adjusted patient days in the regression (not reported in the tables). Moreover, the coefficient on $\ln$ (patient days) itself is, in general, positive.

We also find (not reported in the tables) that total expenses (not expenses per patient day) are positively related to pay. Perhaps hospital managers are rewarded for spending more in general and not just for spending more on medical services per patient.
}

ous for-profit and not-for-profit performance measures. We did not account for the role that $\mathrm{HMO}$ penetration may play in shaping or reshaping that relationship. Hence, while the importance of the forprofit objectives did not appear overwhelming in those earlier regressions (in fact, we found none among the more richly endowed hospitals), this might hide heterogeneity across hospitals based on the level of HMO penetration. The turnover findings in the previous section already suggest that managed care pressures may have caused the removal of less financially oriented managers. More generally, however, HMO penetration may have driven nonprofit boards to reconsider what objectives they want their executives, whether newly appointed or not, to fulfill.

In Table 5, we ask whether, as HMO penetration increases, the sensitivity of top executive compensation to economic measures of performance increases as well. All regressions include year fixed effects and the vector of hospital characteristics. Standard errors are corrected for clustering of the error term at the hospital level.

In columns (1) through (4), we use return on assets as the economic performance measure. Column (1) includes region and city size dummies, as well as return on assets. The coefficient of interest is that on the interaction term between HMO penetration and return on assets. We find that the sensitivity of pay to the rate of return on assets increases with $\mathrm{HMO}$ penetration. The magnitude of the effect is, however, rather modest. For example, in column (1), a 1 percentage point increase in the rate of return on assets increases managerial pay by $0.66 \%$ more for each 10 extra percentage points in HMO market share. ${ }^{23}$

\footnotetext{
${ }^{23}$ Weisbrod and Erus (2003) compared compensation of top managers to that of middle managers in for-profit and nonprofit hospitals using data from 1992 and 1997. They found that reward structures became more equal for the top managers but not for the others. Their idea was that there was a shift toward "commercialism" over the time period they studied.
} 


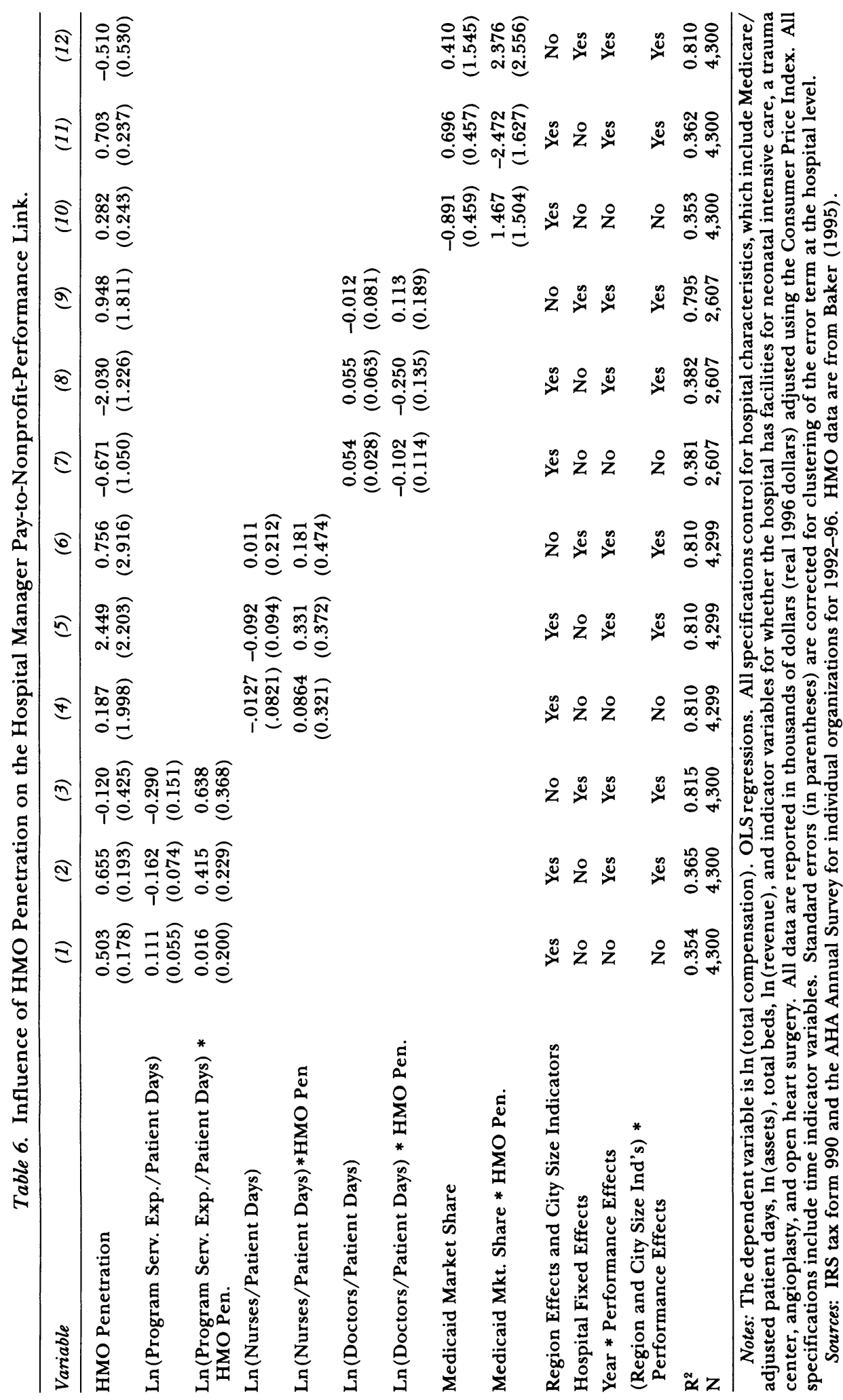


Column (2) explores the possibility that the effect reported in column (1) simply proxies for some overall increase in the link between pay and economic performance over time. Such a time trend could indeed very easily be reflected in a positive coefficient on the interaction term between HMO penetration and economic performance as the HMO penetration variable has been trending up over time. We address this concern by allowing for interaction terms between the year fixed effects and return on assets. The estimated coefficient on "HMO penetration* Return on assets" is both statistically and economically unaffected.

Column (3) explores the sensitivity of this finding to allowing for the pay-forreturn on assets relationship to differ across region and city type. More specifically, column (3) replicates column (2) but adds interaction terms between the region and city size dummies and return on assets. The results are unaffected.

Finally, column (4) replicates column (3) but allows for hospital fixed effects. Again, we find higher pay-for-economicperformance sensitivity when HMO penetration is higher. The magnitude of the interaction effect in column (4) is smaller than in the prior columns (compare 5.490 to 7.089 , for example), but both are statistically significantly different from zero.

In regressions not reported here, we asked whether the tightening of the link between managerial pay and return on assets happens only through the appointment of new executives or whether incumbent managers also experience a change in their compensation package. We replicated the specification in column (4) but replaced hospital fixed effects with hospital-manager fixed effects. The results were again unchanged. Hence, it appears that the stronger pay-for-financial-performance relationship does not only occur through the hiring of new managers. Even incumbent managers appear to experience a change in their compensation package when $\mathrm{HMO}$ penetration increases.

The remaining part of Table 4 is modeled after columns (1), (3), and (4) but focuses on the alternative performance measures. Columns (5) $-(7)$ consider total profit margin, and columns (8)-(10) consider profit margin on program services. The findings on total profitability margins are very similar to those on return on assets. In all specifications, we find there is a stronger (positive) correlation between managerial pay and profit margins when HMO penetration is higher. The results on profit margin on program services are considerably weaker. While the point estimate on the interaction term between HMO penetration and that profitability variable is positive in all regressions, the effect is only close to statistically significant when we allow for fixed differences in managerial compensation across hospitals (column 10) $(p$-value $=0.11) . .^{24}$

Table 6 shows the results from an investigation of whether HMO penetration also affected the financial reward of top hospital executives who provide better patient care and offer more charity care. In Table 4B, we saw that pay responded positively to increases in not-for-profit goals such as the per-patient level of program service expenditures and the per-patient number of full-time doctors. We now ask whether the nature and strength of these relationships were affected by the spread of HMOs.

In columns (1) to (3), we consider the sensitivity of pay to program services expenditures per adjusted patient day. Column (1) allows for year, region, and city size dummies, as well as the vector of hospital characteristics. Column (2) further adds interactions between the year, region, and city size dummies and program services expenditures per patient day. Finally, column (3) replicates column (2) but includes

\footnotetext{
${ }^{24}$ In regressions not reported here, we also studied the relationship between managerial turnover and lagged measures of financial performance, as well as whether this relationship was affected by HMO penetration. Interestingly, we found that turnover, unlike pay, is on average related to (poor) financial performance. We found only weak evidence of that relationship tightening up with $\mathrm{HMO}$ penetration.
} 
hospital fixed effects. ${ }^{25}$ Columns (4)-(6), (7)-(9), and (10)-(12) are modeled after columns (1)-(3) but consider, respectively, number of nurses, number of doctors, and share of Medicaid patients as alternative not-for-profit performance measures.

We find some evidence that the sensitivity of pay to the expenditure measure did in fact increase with HMO penetration (see the interaction term in columns 2 and 3 ). There is no economic or statistical evidence of a change in financial reward for providing a larger number of nurses per patient. While some regressions seem to indicate a more negative reward for a larger number of doctors and larger fraction of Medicaid patients when HMO penetration increases, these findings are not robust across different specifications.

In summary, we find no strong or robust evidence of a direct decline in the financial reward for achieving nonprofit goals. In fact, we find some evidence that the reward for more program spending per patient may have increased with HMO penetration. One must, however, understand that managerial motivation to pursue these nonprofit objectives may be indirectly altered through multi-tasking effects. The higher incentives to increase economic profitability may indirectly hurt the quality of patient care as well as the quantity of charity care provided. ${ }^{26}$

\section{Summary and Conclusion}

Do the cost pressures induced by HMOs change the way not-for-profit hospitals are managed? This paper has provided some evidence on this question through a study

\footnotetext{
${ }^{25}$ We replicate these specifications for a balanced panel, keeping only the hospitals for which we have data for all the years in the sample. The results are qualitatively unaffected.

${ }^{26}$ About $30 \%$ of the hospitals in our sample are training hospitals. Interestingly, our findings of increased turnover (in low-performance hospitals) and increased pay-for-economic-performance sensitivity when HMO penetration is higher are quantitatively stronger in the subsample of training hospitals.
}

of the managerial labor market in these hospitals. Using a unique combination of data sources, we have found that the spread of managed care indeed may have changed the management of nonprofit hospitals. We found that top executive turnover increased with HMO market share, especially among the hospitals that seemed to be most stressed in terms of economic profitability. Also, although the relationship between economic performance and top managerial pay in nonprofit hospitals was on average extremely weak, we found that it strengthened with higher rates of HMO penetration. The evidence in this paper is consistent with the idea that nonprofit hospitals experiencing negative shocks to their revenues may appoint new managers who are better able to compete in the new market environment and reward old and new managers more for achieving for-profit goals. The economic magnitude of these HMO-related changes is, however, rather small, at least as indicated by our results for the period under study here.

One extreme interpretation of our findings would be that HMOs have altered the mission of not-for-profit hospitals. However, our findings could also be framed in a much less radical light. Indeed, an important part of the not-for-profit mission might be to ensure that a high quality of care is provided not only to today's patients but also to future generations of patients. In other words, the long-run survival of the organization itself might be an important part of the not-for-profit mission. Achieving survival might then very naturally lead nonprofit boards to increase financial incentives when income-reducing shocks hit. ${ }^{27}$

\footnotetext{
${ }^{27}$ In tests not reported here, we investigated the idea that donors may perceive some of the changes we have highlighted as a weakening of the nonprofit mission (and not simply an attempt by altruistic boards to protect intergenerational equality). Consistent with this view, we found that public donations fall as the HMO market share increases. This effect on donations is, however, both statistically weak and economically small.
} 
A possible future extension of this work would be to focus on comparing the changes that we witness in the not-for-profit sector to the changes that may have occurred among for-profit hospitals. ${ }^{28}$ Of special interest would be to study trends in top managerial pay in both organizational forms over time and as market conditions evolve.

What is the social efficiency of promoting the development of not-for-profit organizations in sectors where strong market forces are at play? To what extent do policy-

${ }^{28}$ Unfortunately, such data are extremely difficult to obtain. makers want to continue giving tax breaks to nonprofit organizations if they are increasingly behaving like for-profits? These are theoretically important questions, especially in the context of the growing commercialization of many sectors of the economy that were historically dominated by not-for-profits. The qualitative changes in the management of not-for-profit hospitals suggested by this paper provide an empirical backdrop for the relevance of these questions. Future research should assess how generalizable our findings are to other not-for-profit sectors and other forms of income-reducing shocks. We hope that our work is a useful first step.

\section{REFERENCES}

Abelson, Reed. 1998. "Nonprofit Work Gets Profitable." New York Times, Sunday, March 29.

Baker, Laurence C. 1995. "County-Level Measures of HMO Enrollment and Market Share." Working Paper, Stanford University.

Baker, Laurence C., and Martin L. Brown. 1999. "Managed Care, Consolidation among Health Care Providers, and Health Care: Evidence from Mammography." Rand Journal of Economics, Vol. 30, No. 2 (Summer), pp. 351-74.

Baker, Laurence C., and Kenneth S. Corts. 1996. "HMO Penetration and the Cost of Healthcare: Market Discipline or Market Segmentation?" American Economic Review Papers and Proceedings, Vol. 86, No. 2 (May), pp. 389-94.

Baker, Laurence C., and Sharmila Shankarkumar. 1998. "Managed Care and Health Care Expenditures: Evidence from Medicare, 1990-1994." In Alan Garber, ed., Frontiers in Health Policy Research, Vol. 1. Cambridge, Mass.: MIT Press.

Ballou, Jeffrey P., and Burton A. Weisbrod. 2003. "Inferring Differences in the Behavior of For-Profit, Governmental, and Nonprofit Organizations from Managerial Rewards: Evidence from the Hospital Industry." Journal of Public Economics, Vol. 87, Nos. 9-10, pp. 1895-1920.

Brickley, James A., and R. L. Van Horn. 2002. "Incentives in Nonprofit Organizations: Evidence from Hospitals." Journal of Law and Economics, Vol. 45, No. 1 (April), pp. 227-50.

Currie, Janet, and John Fahr. 2004. "Hospitals, Managed Care, and the Charity Caseload in California." Journal of Health Economics, Vol. 23, No. 3 (May), pp. 421-42.

Cutler, David M., ed. 2000. The Changing Hospital Industry: Comparing Not-For-Profit and For-Profit Institutions. Chicago, Ill.: University of Chicago Press.
Cutler, David M., and Jill R. Horwitz. 2000. "Converting Hospitals from Not-For-Profit to For-Profit Status: Why and What Effects?" In David M. Cutler, ed., The Changing Hospital Industry: Comparing ForProfit and Not-For-Profit Hospitals. Chicago: University of Chicago Press, pp. 45-79.

Cutler, David M., and Janice Seinfeld. 2000. Managerial Background and Decision Making: Evidence from the Hospital Industry. Working Paper, Harvard University.

Drucker, Peter F. 1992. Managing the Non-Profit Organization: Practices and Principles. New York: Harper Collins.

Duggan, Mark G. 2002. "Hospital Market Structure and the Behavior of Nonprofit Hospitals." Rand Journal of Economics, Vol. 33, No. 3 (Autumn), pp. 433-46.

Duke, Kathryn. 1996. "Hospitals in a Changing Health Care System.” Health Affairs, Vol. 15, No. 2, pp. 49-61.

Frank, Richard G., and David S. Salkever. 2000. "Market Forces, Diversification of Activity, and the Mission of Not-For-Profit Hospitals." In David M. Cutler, ed., The Changing Hospital Industry: Comparing Not-For-Profit and For-Profit Institutions. Chicago: University of Chicago Press, pp. 195-215.

Goddeeris, John H., and Burton A. Weisbrod. 1998. "Conversion from Nonprofit to For-Profit Legal Status: Why Does It Happen and Should Anyone Care?" In Burton A. Weisbrod, ed., To Profit or Not to Profit: The Commercial Transformation of the Nonprofit Sector. Cambridge, Mass.: Cambridge University Press, pp. 129-48.

Glaeser, Edward L., and Adrei Shleifer. 2001. "NotFor-Profit Entrepreneurs." Journal of Public Economics, Vol. 81, No. 1 (April), pp. 99-115.

Hallock, Kevin F. 2002. "Managerial Pay and Gover- 
nance in American Nonprofits." Industrial Relations, Vol. 41, No. 3 (July), pp. 377-406.

2004. "Managerial Pay in Nonprofit and ForProfit Organizations." In Ronald Riggio and Sarah Smith Orr, eds., Improving Leadership in Nonprofit Organizations. San Francisco: Jossey-Bass, pp. 76101.

Hansmann, Henry B. 1996. The Organization of Enterprise. Cambridge, Mass.: Harvard University Press.

Jensen, Michael C., and Kevin J. Murphy. 1990. "Performance Pay and Top Management Incentives." Journal of Political Economy, Vol. 98, No. 2 (April), pp. 225-64.

Murphy, Kevin J. 1985. "Corporate Performance and Managerial Remuneration: An Empirical Analysis." Journal of Accounting and Economics, Vol. 7, Nos. 1-3, pp. 11-42.

Nemes, J. 1992. “Hospital Executives' Pay Beginning to Raise Eyebrows." Modern Healthcare Weekly Business Review, June 8, pp. 41-52.

Newhouse, Joseph P. 1970. "Toward a Theory of Nonprofit Institutions: An Economic Model of a Hospital." American Economic Review, Vol. 60, No. 1 (March), pp. 64-74.

Oster, Sharon M. 1998. "Executive Compensation in the Nonprofit Sector." Nonprofit Management and Leadership, Vol. 8, No. 3, pp. 207-21.

Pink, George H., and Peggy Leatt. 1991. “Are Man- agers Compensated for Hospital Financial Performance?" Health Care Management Review, Vol. 16, No. 3, pp. 37-45.

Preyra, Colin, and George Pink. 2001. "Balancing Incentives in Compensation Contracts of Nonprofit Hospital CEOs." Journal of Health Economics, Vol. 20, No. 4 (July), pp. 509-25.

Roomkin, Myron J., and Burton A. Weisbrod. 1999. "Managerial Compensation in For-Profit and Nonprofit Hospitals: Is These a Difference?" Journal of Law, Economics, and Organization, Vol. 15, No. 3, pp. 750-81.

Stevenson, David R., Thomas H. Pollak, Linda Lampkin, Kathryn L. S. Pettit, and Nicholas A. J. Stengel. 1997. State Nonprofit Almanac 1997: Profiles of Charitable Organizations. Washington, D.C.: Urban Institute.

United States Internal Revenue Service. 1996. Instructions to Form 990.

Weisbrod, Burton A., ed. 1998. To Profit or Not to Profit: The Commercial Transformation of the Nonprofit Sector. Cambridge, Mass.: Harvard University Press. Weisbrod, Burton A., and Burcay Erus. 2003. “Objective Functions and Compensation Structures in Nonprofit and For-Profit Organizations: Evidence from the 'Mixed' Hospital Industry." In Edward Glaeser, ed., The Governance of Not-For-Profit Organizations. Chicago: NBER and the University of Chicago Press. 